\title{
Article
}

\section{Cross-border teaching experiences in Canada and the U.S.: A writing teacher reflects}

\author{
Laura Dunbar \\ SUNY Cortland
}

\section{Abstract}

A writing teacher reflects on her professional experiences in the U.S. and in Canada. This personal narrative focuses on the incongruencies the practitioner notices between faculty representation and program recognition in her roles first as a Limited Term Appointment Assistant Professor of Composition and Professional Writing at a Canadian university, and, next, as a tenure-track instructor of writing at a U.S. college. Programmatic differences are attributed to the historic visibility of First-Year Composition in the United States, greater numbers of faculty, and the increased allocation of resources to program development and faculty support.

In September 2018, I moved from central Canada to start a tenure-track teaching-stream job as a writing instructor at a northeastern U.S. university. In thinking about my Canadian and U.S. experiences as a teacher-scholar of writing, it strikes me that my emigration has enacted in reverse what Coe (2006) refers to as Kenneth Burke's "perspective of incongruity" that U.S. immigrants to Canada may employ to make sense of their experiences. In particular, Coe draws attention to the important pedagogical function that certain words and phrases-civility, responsible government, separatism, multicultural mosaic_can have for newcomers to Canada from the United States. He argues that close attention to these commonplaces can help challenge the "just like us" assumptions held by some U.S. newcomers to Canada (p. 25).

Though Coe's 1988 essay was first published in College English, a U.S. scholarly journal, and at a time when some were arguing that 1987's Free Trade Agreement was eroding Canada's cultural distinctiveness, its inclusion in Graves and Graves' 2006 Writing Centres, Writing Seminars, Writing Culture: Writing Instruction in Anglo-Canadian Universities suggests that the intervening three 
Volume 29, 2019

http://journals.sfu.ca/cjsdw

decades have emphasized rather than diminished some of our nationalist differences. And yet, then as now, many of our disciplinary issues transcend borders; these commonplaces are beginning to result in research that takes a wider-scale, North American approach (Mueller, Williams, Wetherbee Phelps \& Clary-Lemon, 2017). By inviting those of us with professional experiences in both countries to share our perspectives, the editors of this special section of $C J S D W / R$ create space for practitioners to contribute to this new wave of scholarship and to explore some of the ways our common issues may be realized differently in their international contexts.

In sharing my first-person narrative, which compares aspects of my experiences in Canada and the U.S., I hope to contribute a little to the advancement of this local/international comparison conversation in our scholarship. To that end, in what follows I have taken a cue from Coe's model to analyze the congruities and incongruencies between my experiences in a Canadian Limited Term Appointment (LTA) and in a U.S. tenure-track instructorship.

My first full-time job in Writing Studies was in a Limited Term Appointment (LTA) at an urban Anglo-Canadian university. Hired as an Assistant Professor of Composition and Professional Writing in an English Department while I was in the final stages of my doctoral studies in a literary program, I joined a Composition project that had begun in 1983 as a response to the illiteracy crisis of the 70s; the Professional Writing (PW) stream was a later addition. The majority of the composition students came from the university's School of Business. The business students had to achieve a particular composition-course level in order to graduate from their major; many were International EAL students who had previous courses in English for Academic Purposes and so approached the program's placement test with high hopes for exemption. However, the composition classes below the required course level by one or even two courses were generally full across several sections; clearly, a gap existed between the program's and the students' assessment of their writing ability.

Just as vigorous in terms of its potential and enrollment numbers, the Professional Writing minor's potential for expansion was readily apparent to anyone interested enough to look. Many of the PW students were translation majors; moreover, the city's thriving start-up culture meant that young writers had many opportunities to practice the skills they acquired in the PW program. The contractually limited term meant that my partner and I decided we wouldn't relocate across provinces, but that I would instead rent a room and make the five-hour journey to work by train twice every week. This I did for three years. In the final year, a series of surprising circumstances resulted in my becoming the interim coordinator for both streams of the program. 
Volume 29, 2019

http://journals.sfu.ca/cjsdw

I had little formal training and no experience, and I undertook the coordinator's role with no extension of my contract as an LTA. I was able to function only as a result of the strength of the edifice and the wealth of resources left to me by the program's long-time, outgoing director and the unflagging support of senior part-timers. Two of these expert "writing ladies," to use the words of Kathryn Alexander (2005), became my greatest allies and guides. Each had also served as LTAs in the same role, only to find out that they would lose their part-time seniority if they served into the appointment's third year. Both practitioners were experienced writing teachers in possession of Master's degrees from the English Department in question and the respect of the writing program's students and other part-time faculty. These attributes, however, did not matter in terms of their prospects for a tenured full-time job as the program coordinator; nor did the fact that they knew the ins and outs of the program as well as the director and certainly better than me. The basic inequity in the system meant that the relief of a full-time job was a temporary lure on which hung the hook of their future contingent security.

Beside the Sisyphean tasks involved with writing program administration (WPA), my time as an LTA was the catalyst for the realization that the research I wanted to do was not connected to literature but to Writing Studies. My vocational turning point arose from the questions I had that were direct consequences of issues that I encountered administratively and in the classroom. For instance, inspired to try to revise our program's mission statement to better reflect the changes that had taken place in both our student demographics and the course offerings, I discovered the field of WPA. Wondering how to improve our placement process led me to the literature on placement and Basic Writing. (After finding Mina Shaughnessy's Errors and Expectations, I shut my office door for several afternoons in a row to read it undisturbed.) Curiosity about the program's history led me to the University Senate archives and Bruce McComiskey's Microhistories of Composition. Standardized exams led me to question the cultural assumptions and ethical implications underpinning our approaches to rhetoric and the composing process. A roster of long-established composition courses emphasizing grammar and form over rhetorical agility made me uneasy at first and, later, firmly convinced we needed to re-think our pedagogical aims. (I was a proud member of the program's first-ever working group, which came together specifically to draft a program mission statement.) I struggled for six months with the university's room allocations services to secure computer-supported classrooms for our students. I spent hours grading mandatory placement tests by myself. And, inevitably, a university colleague arrived at my door one afternoon, loaded for shots 
Volume 29, 2019

http://journals.sfu.ca/cjsdw

across my bow, demanding to know why "my program" was passing students who still could not write a single correct English sentence.

In many ways, my Canadian entry into our field was a through-the-looking glass experience. Incongruencies beset the apparently smooth surfaces of the Composition and Professional Writing programs in which I found my intellectual home. I now realize I was running headfirst into several of the concrete realities resulting from what Landry (2016, p. 63), in her "people's history" of Canadian writing instruction, calls the myths, or meta-narratives, historically connected to Canadian writing programs: that writing instruction is a remedial, non-theoretical-and thus nonscholarly-activity; that placement testing is a sound diagnostic; that grammar instruction is the cornerstone of improved writing; and that if teachers of writing were any good at all, we would be able to 'fix' students in a single course.

It also became increasingly significant to my self-identification with Writing Studies that the LTA fell under the purview of a literature department, a situation familiar to many of us on both sides of the border. Over time I began to believe that the program was not so much under-appreciated by individual faculty members as it was generally subsumed under the priorities given to the department's 'real' business of literary criticism-what Nan Johnson traces to the eighteenthcentury British pedagogical model that has been so pervasive throughout the history of Canadian Writing Studies (2006, p. 44). Individually, most of the literary and creative writing faculty were attentive and receptive to the two streams of the writing program; I was even asked on several occasions to produce formal proposals for the program's expansion, which were warmly welcomed. But, I noticed that there was very little in the way of concrete advancement afterward. There was also the remark during one faculty meeting that the department had to be careful about not letting itself become overwhelmed by the "leviathan" model of "Comp/Rhet" in the United States. The speaker was a U.S. ex-pat who believed that many English departments in the U.S. had been negatively affected by writing programs that had outpaced the study of literature. I felt there was little danger of this happening. Some of my colleagues seemed surprised that there was a deep body of research about the teaching of writing outside of English Language Learning programs. Some, I came to believe, were just not aware that scholars and teachers of writing might constitute a discipline quite separate from literary studies, while others were alert to, but wary of, Writing Studies as a field.

Despite these frustrations, I loved my job. As the scholarly possibilities in Writing Studies took hold, teaching became more fulfilling; for me, the two activities are intertwined in ways that mirror 
Volume 29, 2019

http://journals.sfu.ca/cjsdw

Writing Studies' historical meta-narrative. Indeed, my growing belief that a better understanding of our field's research was indispensable led me not to apply for the Extended Term Appointment the department advertised at the end of my LTA. I was convinced that I needed to go back to school and receive formal training in the theory and methods of Writing Studies to understand what I was doing and to do it well. I decided to apply to do a doctorate that would support my goal.

At the end of the third semester of my new program, the summer of 2018, I was lucky enough to be in the position for the first time of choosing between two jobs: one, a full-time, one-year contract as a writing teacher in the English Department at my Canadian doctoral institution; the second, a new tenure-track teaching instructorship at a northeastern state university. Both were attractive positions; however, the U.S. position won out for me. Of course, there was the immediate appeal of full-time, tenure-track employment, which was made easier by my U.S. citizenship (though hindsight cautions me to add that there was a bewildering and sometimes byzantine amount of paperwork involved in the move, even with my citizenship in hand). More importantly, the U.S. position offered an opportunity to become part of a program with a different-for lack of a better word- bearing than any I had known.

Along with a vigorous First-Year Composition program in which a new Developmental English program has been added-an area of particular research interest to me-the program also includes a Professional Writing minor and major, where the second of my scholarly interests lies. I like the way this school's egalitarian culture mirrors aspects of my Canadian LTA. For example, a substantial number of our students are the first in their families to attend a post-secondary institution; many arrive as transfer students. Unlike my former Canadian writing programs, at this campus there are few multilingual or international learners. As I was with their Canadian counterparts, I am humbled by the conscientious goodwill my U.S. students show their writing courses and teachers. Like my LTA, the program I joined is located in an English department.

A substantial body of scholarship discusses the complex relations that arise when writing programs-such as the Professional Writing program in which I also teach in my current U.S. school-are housed in literary studies departments (Deans, 2007; MacNealy \& Heaton, 1999; Mahala \& Swilky, 2016; Mendelson, 1994; Renz, 2001; Sullivan \& Porter, 1993). It is not my purpose here to discuss the valences of those relationships; instead, I feel it is important to note what was for me, at least, a somewhat surprising intersection between my U.S. and Canadian programs: the role that geographic place assumes in writing program identity. As my research partner Judy Cuggy Lapalme and I explore in our in-progress micro-history of the Canadian 
Volume 29, 2019

http://journals.sfu.ca/cjsdw

program, being a member of an Anglophone writing program in a bustling cosmopolitan Quebec city shapes the self-understandings and practices of the writing program faculty in specific ways; as I have discovered this year, so does being a mid-state college that draws heavily on a Long Island student demographic, and which occupies a central role of its surrounding small city. In this way, I have come to realize that the now-classic Canadian "where is here?" rumination-or what Wetherbee-Phelps (2014) calls 'territoire'-is not restricted to Canadian struggles with identity formation in Writing Studies, but plays a significant role in U.S. programs, too.

Among the incongruencies I'm noticing in my new position, two seem particularly significant when I compare them to my Canadian experience.

First, the historical tradition of First-Year Composition (FYC) in the United States carries weight. I say this to draw attention to the fact that although the Canadian composition program had a decades-old tenure in its home department, it had little or no visibility outside of the few majors with which it was partnered, and even then, in my experience the program was seen by many of its external observers to comprise little more than a series of obscure course requirements. In this way, the historical context of the Canadian program was not grasped by non-writing faculty even while though those on the inside knew its story well. It became a major frustration-and soapbox-of mine, in that I felt that this lack of historical sense was tied to the program's underrecognized stature not just in the department but also in the greater campus community.

In contrast, in terms of campus visibility, the FYC model means that unless they qualify for exemptions, the majority of incoming first-semester students at my current institution take a twocourse composition sequence regardless of their disciplinary intentions. In a real way, then, the writing program is everywhere. The focus in the first-semester course is on critical thinking and reading; in the second, on the development of research skills. One of the common texts is compiled and edited by composition faculty and features examples of student work-a project I find admirable indeed, both for the way it valorizes local and sometimes part-time writing faculty as scholarly experts and editors, and for the way that it showcases students as developing writers.

In both semesters, students spend two weeks in computer-supported writing labs so that they can develop their technology skills; in the second semester, writing faculty partner with librarians in two well-organized sessions to help students develop research skills. Though these seem like small activities, the fact that they are built into the composition sequence means that faculty are not left to negotiate these things by themselves. In turn, it becomes an infrastructure that helps build continuity across the many sections. In my previous Canadian program, procuring computer- 
Volume 29, 2019

http://journals.sfu.ca/cjsdw

supported classrooms was left up to individual teachers, and, as I pointed out earlier here, it was an exhausting and often futile task. It seems to me that having these activities managed with the support of the program and the wider institutions does a great deal to foster cohesive culture between the composition program, the literature department in which it is housed, and the wider university network.

By using the word "cohesive", I do not mean to oversimplify the complex. However, I believe that the visibility and confidence of the composition faculty here significantly change the relations of writing faculty to the institution's culture. On my worst days in the Canadian program, I identified with Susan Miller's (1991) description of sad basement labourers. I do not feel I have joined a group that could be characterized that way here. First, a majority of the faculty in the Professional Writing program have doctorates in Composition and Rhetoric, not literature. Second, the leadership structures of both the Composition and Professional Writing programs within the department have a different architecture, both within the department and across the institution. Our department Chair occupies a primary leadership role in all of the department's programs, of course, and is committed to actively supporting the writing programs. The Composition program is guided by the Director of Campus Writing Programs, a title which includes campus-wide Writing Across the Curriculum (WAC) initiatives (like writing-intensive courses), the regular First-Year Composition program, and the new Developmental English program (designed to aid first-semester students who need more support). The longest-serving faculty member connected to the Professional Writing program is the Chair of the Curriculum Committee for Professional Writing. The Professional Writing faculty have been working closely to plan the program's future and recently participated in an external departmental review process in which they had their own session with the reviewers. The composition faculty meet for teaching circles on a monthly basis, building a sense of community in the discussion of our unique pedagogical goals. In these and myriad other ways, the particular and unique topography of Writing Studies is matter-of-factly understood to exist.

Next, there are more writing faculty here than in my LTA program. Though the problems that arise with contract faculty structures are much the same as I understood them in Canada, there are things that can result from critical mass. There is, especially, a widely recognized historical narrative attached to the faculty, past and present, in the American writing program, whose numbers alone make them a major presence in the English Department. Composition faculty played, and continue to occupy, critical roles in the formation of the union that now supports 
Volume 29, 2019

http://journals.sfu.ca/cjsdw

faculty across my current university; their roles in the deep and rich tradition of activism in the ranks have been described to me over and over by people inside and outside of the department and program. As well as the solidarity of its full-time lecturer base, the writing program's leadership initiatives have resulted in new job lines-I was one of three people hired in newly created instructor positions, all of which were connected either to the Composition or the Professional Writing and Rhetoric programs. But I am still navigating my personal location in this new environment. It is not always clear to me how the instructorship is viewed by my new colleaguesam I closer in cultural kinship to the Full-Time Lecturers or the Assistant Professors? I am not sure; because the position is so new, I think those relations are still in their formative stages.

Along with my uncertainty about how others see the instructorship comes my adaptation to other new institutional expectations. As I think all writing teachers do, I have an ongoing pedagogical concern about the disjunctures that might arise between my teaching philosophy and the institutionalized expectations of writing teachers, or what Janna Klostermann (2017) sometimes notes can turn into the undervaluation of students' own "thinking, knowing, and writing practices...[which can result in programs aligned] more with the priorities of university administrators than with the slow, steady, and sometimes disappointing work of student writers" (p. 21). Some dilemmas associated with the teaching of writing are global: so are some gifts. As I was lucky previously with the part-time colleagues who welcomed me so warmly in my LTA role, I have been fortunate again to have a writing program director of exceptional vision and energy who has been unflagging in her willingness to support my professional growth and acculturation to the program, and, more widely, to the discipline.

So much of my recent growth is a result of the habits of comparison that I am drawn to reflect on the balance of my experiences. The development I see in the U.S. program, supported by external recognition and the resources of the department and wider institution, would have made positive differences to the professional lives of my Canadian colleagues. At the same time, I owe my Canadian colleagues and my LTA experience an enormous debt. After all, without those incredibly formative experiences I would not be in my current role at all and would not have found my life's absorbing work. And things change. While I earlier expressed my frustration at the minimal momentum I felt had happened in terms of program development while I was in the Canadian LTA position, this program is now about to implement a cooperative learning initiative in its Professional Writing program, an encouraging new direction. I hope the person who has played a key role in its conception and planning-one of the part-time faculty members upon whom I relied 
Volume 29, 2019

http://journals.sfu.ca/cjsdw

so heavily during my LTA-is recognized for her dedicated work supporting the program, its students, and the wider institution.

Finally, I feel I must address the obvious issue for many of us in, or considering, a tenure-track instructor-rank teaching position. Despite the potential security of this instructorship, I am still concerned about whether I will be able to pursue the kinds of research I hope to do, given my significant teaching responsibilities. While Vajocki, Fenton, Menard, and Pollon (2011) report that 75 per cent of Ontario teaching stream faculty are "generally satisfied and committed" in their roles, they also note that there is evidence suggesting that excellent teaching and a strong research agenda rarely accompany each other (para. 5-6). In counterpoint, Thieme (2017) points out in a blog post that departmental models exist in Canada which challenge the oft-cited rule that teachingstream positions preclude strong research agendas. To this I can attest: I am the beneficiary, in my program, of many of the same positive "educational leadership" activities-- pedagogical innovation, professional development, and support for research-that Thieme describes as being part of her UBC community. In my current program, professional development opportunities abound; along with the aforementioned teaching circles, I can choose from a variety of workshops, seminars, and conferences aimed at supporting the growth of teaching-stream writing faculty. My research program is actively encouraged by an excellent program director, and funding exists to provide me with practical support. I have been given opportunities to explore Applied Learning pedagogy and to help first-year writers present their research at a campus-wide undergraduate research conference.

My "future file" has many interesting research projects flowing from these supported activities, and I have new research goals for my doctoral work that have grown out of the First-Year Composition programs here...and yet as Thieme and Landry also observe, the conflict between teaching and research is structural and transcends international borders. There are only so many hours in a day-and these seem shorter as I get older. The fact is that I struggled to find the time to write even this brief first-person, anecdotal narrative. Having been inspired by our field's scholars, I'm now acutely aware of the ways that the time pressures of a teaching-oriented job promise to affect my own research activity, even as I am grateful for the luxury of the position's security. I hope my story invites others to share theirs, and that by doing so our cross-border perspectives strengthen our shared identifications and our understanding of their differences. 
Volume 29, 2019

http://journals.sfu.ca/cjsdw

\section{References}

Alexander, K. (2005). Liminal identities and institutional positioning: On becoming a 'writing lady' in the academy. Inkshed: Newsletter of the Canadian Association for the Study of Language and Learning, 22(3), 5-16.

Coe, R.M. (2006). Anglo-Canadian rhetoric and identity: A preface. In Roger Graves \& Heather Graves, (Eds.), Writing centres, writing seminars, writing culture: Writing instruction in AngloCanadian universities (pp. 23-41). Winnipeg, MB: Inkshed/Trafford.

Deans, T. (2007). Shifting locations, genres, and motives: An activity theory analysis of servicelearning writing pedagogies. In C.J. Keller \& C.R. Weisser (Eds.), The locations of composition, (pp. 289-306). Albany, NY: State University of New York Press.

Johnson, N. (2006). Rhetoric and belles lettres in the Canadian academy: An historical analysis. In Roger Graves \& Heather Graves, (Eds.), Writing centres, writing seminars, writing culture: Writing instruction in Anglo-Canadian universities (pp. 43-59). Winnipeg, MB: Inkshed/Trafford.

Kent, T. (2007). The "remapping" of professional writing. Journal of Business and Technical Communication, 21(1), 12-14.

Klostermann, J. (2017). Writing on the ground. Canadian Journal for Studies in Discourse and Writing/Rédactologie, 27, 19-23.

Landry, D.L. (2016). Writing studies in Canada: A people's history. UBC Theses and Dissertations. https://open.library.ubc.ca/cIRcle/collections/ubctheses/24/items/1.0308778.

MacNealy, M. S., \& Heaton, L. B. (1999). Can this marriage be saved: Is an English department a good home for technical communication? Journal of Technical Writing and Communication, 29(1), 4164.

Mahala, D. \& Swilky, J. (2016). Constructing disciplinary space: The borders, boundaries and zones of English. Journal of Advanced Composition, 23(4), 765-97.

McComiskey, B. (2016). Microhistories of composition. Logan, UT: Utah University Press.

Mendelson, M. (1994). Professional communication and the politics of English studies. WPA: Writing Program Administration, 17(3), 7-19.

Miller, S. (1991). Textual carnivals: The politics of composition. Carbondale, IL: Southern Illinois University Press.

Mueller, D., Williams, A., Wetherbee-Phelps, L. \& Clary-Lemon, J. (2017). Cross-border networks in Writing Studies. Edmonton, AB: Inkshed; Anderson, SC: Parlor Press. 
Volume 29, 2019

http://journals.sfu.ca/cjsdw

Renz, Kathryn. (2001). A flare from the margins: The place of Professional Writing in English departments. Pedagogy 1(1), 185-90.

Shaughnessy, M. (1977). Errors \& expectations: A guide for the teacher of basic writing. New York, NY: Oxford University Press.

Sullivan, P. A. \& Porter. J. (1993). Remapping curricular geography: Professional writing and/in English. Journal of Business and Technical Communication,

7 (4), 389-422. https://doi.org/10.1177/1050651993007004001

Thieme, K. (2017, December 2). On swimming in the tenure-track stream.

https://medium.com/@KatjaT/on-swimming-in-the-tenure-track-teaching-stream-

$8 \mathrm{c} 87 \mathrm{cfd} 2 \mathrm{dfe} 6$.

Thieme, K., \& Landry, D. (unpublished manuscript). From Literary to Writing Studies: Ghost stories in the academic machine.

Vajoczki, S., Fenton, N., Menard, K., \& Pollon, D. (2011, October 20). Teaching-stream faculty in Ontario Universities. http://www.heqco.ca/SiteCollectionDocuments/TeachingStream\%20Faculty\%20in\%200ntario\%20Universities.pdf

Wetherbee Phelps, L. (2014). The historical formation of academic identities: Rhetoric and composition, discourse and writing. Canadian Journal for Studies in Discourse and Writing/Rédactologie, 25(1), 3-25. 